\title{
Sistem Pendukung Keputusan Perekrutan Karyawan Menggunakan Metode TOPSIS di PT Visionet Data Internasional
}

\author{
Ramos Somya ${ }^{1}$, Andre Wahyudi ${ }^{2}$ \\ 1,2 Fakultas Teknologi Informasi, Universitas Kristen Satya Wacana \\ e-mail: ${ }^{1}$ ramos.somya@uksw.edu, ${ }^{2}$ 672016038@student.uksw.edu
}

\begin{abstract}
Abstrak
PT Visionet Data Internasional merupakan salah satu perusahaan terbesar dalam bidang penyedia layanan pengelola IT di Indonesia. Atas capaian prestasi tersebut, perusahaan membutuhkan karyawan dengan kualitas yang sesuai dengan kriteria yang dibutuhkan. Namun pada kenyataannya, masih banyak perusahaan yang mengalami kesulitan dalam proses perekrutan karyawan. Hal ini disebabkan oleh banyak faktor seperti banyaknya kriteria penilaian yang menjadi tolak ukur dalam proses penerimaan karyawan. Salah satu cara untuk menyelesaikan permasalahan tersebut adalah membuat sistem pendukung keputusan yang menerapkan salah satu metode MCDM. TOPSIS merupakan metode MCDM yang dapat digunakan pada sistem pendukung keputusan tersebut. Metode ini memberikan kelebihan konsep yang sederhana dan mudah dipahami, komputasi yang efisien dan dapat mengukur kinerja relatif dari alternatif keputusan dalam bentuk matematis yang sederhana. Pada penelitian ini dirancang sistem pendukung keputusan yang dapat digunakan oleh perusahaan untuk memberikan alternatif keputusan dalam proses rekrutmen karyawan. Hasil yang didapatkan dari penelitian ini adalah sebuah sistem pendukung keputusan yang dapat digunakan oleh Admin HRD untuk membantu proses rekrutmen karyawan.
\end{abstract}

Kata Kunci : Sistem Pendukung Keputusan, MCDM, Metode TOPSIS, Perekrutan Karyawan, Web

\begin{abstract}
Visionet Data Internasional Inc is one of the largest companies in the field of IT management service providers in Indonesia. For this achievement, the company needs employees with quality in accordance with the criteria needed. But in reality, there are still many companies that experience difficulties in the process of hiring employees. This is cause by many factors such as the many assessment criteria that serve as benchmarks in the recruitment process.One way to solve this problem is to create a decision support system that applies one of the MCDM methods. TOPSIS is a MCDM method that can be used in the decision support system. This method provides the advantages of concepts that are simple and easy to understand, computationally efficient and can measure the relative performance of alternative decisions in a simple mathematical result. In this research, a decision support system is designed that can be used by companies to provide alternative decisions in the employee recruitment process. The result of this research is a decision support system that can be used by the HRD Admin to assist the employee recruitment process.
\end{abstract}

Keywords: Decision Support System, MCDM, TOPSIS Method, Employee Recruitment, Web

\section{Pendahuluan}

Perkembangan teknologi informasi dan komunikasi telah mengalami peningkatan pemanfaatan dalam berbagai bidang kehidupan manusia. Dengan adanya teknologi akan memberikan perubahan yang cukup signifikan menuju ke arah era digitalisasi modern. Salah satu bentuk pemanfaatan teknologi informasi adalah membantu manusia dalam mendukung analisis ad hoc data, pemodela keputusan, orientasi keputusan dan orientasi perencanaan masa depan yang dibuat melalui sistem pendukung keputusan. Sistem pendukung keputusan merupakan suatu cara untuk membuat keputusan yang spesifik dalam memecahkan permasalahan yang spesifik pula (Syafrizal, 2010).

PT Visionet Data Internasional adalah sebuah perusahaan yang bergerak dalam bidang total IT managed services dengan menyediakan layanan dalam membantu dan mendukung operasi teknologi informasi secara optimal. Saat ini 
PT Visionet Data Internasional telah berkembang dengan pesat karena dapat memberikan pelayanan yang sesuai dengan ekspektasi pelanggan. Hal ini terbukti dengan diraihnya penghargaan sebagai salah satu perusahaan penyedia total IT managed services terbesar di Indonesia. Dengan adanya pencapaian tersebut, maka dibutuhkan karyawan dengan kualitas yang memenuhi standar kriteria perusahaan. Namun dalam pratiknya, masih ditemukan kesulitan dalam pengambilan keputusan penerimaan karyawan baru.

Adanya permasalahan tersebut disebabkan banyaknya kriteria penilaian yang harus dipertimbangkan serta melibatkan beberapa orang dalam pengambilan keputusan. Untuk mengatasi permasalahan tersebut, perlu untuk dibuat sebuah sistem pendukung keputusan perekrutan karyawan baru di PT Visionet Data Internasional agar proses perekrutan karyawan baru menjadi lebih baik. Batasan masalah dalam penelitian ini adalah 1) Perancangan sistem pendukung keputusan dibuat untuk membantu PT Visionet Data Internasional dalam perekrutan calon karyawan baru. 2) Sistem pendukung keputusan dibuat menggunakan metode TOPSIS. 3) Kriteria penilaian yang digunakan berdasarkan kriteria umum perekrutan karyawan PT Visionet Data Internasional. 4) Fokus penelitian ini adalah pada penerapan metode TOPSIS ke dalam sistem yang dibangun dalam bentuk website sebagai sarana penghubung data dari client ke server.

Tinjauan Pustaka

Pada penelitian sebelumnya yang berjudul "Perancangan Sistem Pendukung Keputusan Seleksi Asisten Dosen Menggunakan Kombinasi Metode Profile Matching dan TOPSIS Berbasis Web Service" telah membahas permasalahan seleksi asisten dosen di Fakultas Teknologi Informasi Universitas Kristen Satya Wacana (UKSW) yang masih menggunakan form pendaftaran yang ditulis manual untuk proses pendaftarann dan proses seleksi asisten dosen yang masih memakan waktu lama. Untuk mengatasi permasalahan tersebut, dirancang sebuah sistem pendukung keputusan untuk seleksi asisten dosen menggunakan kombinasi metode Profile Matching dan TOPSIS dengan teknologi Web Service. Hasil penelitian ini berupa perhitungan perangkingan calon asisten dosen baru yang akan diterima (Somya \& Wardoyo, 2019).

Pada penelitian sebelumnya yang berjudul "Sistem Pendukung Keputusan Dalam Menentukan Karyawan Terbaik Pada PT Tembaga Mulia Semanan Dengan Metode TOPSIS" telah membahas permasalahan pemilihan karyawan terbaik yang tidak menggunakan metode dalam penilaiannya sehingga masih manual dan subyektif. Untuk mengatasi permasalahan tersebut, dibuat sebuah sistem pendukung keputusan dengan menggunakan metode TOPSIS. Hasil dari penelitian ini berupa aplikasi web yang dapat menunjukan hasil perhitungan karyawan terbaik (Widianto, 2016).

Pada penelitian sebelumnya yang berjudul "Penerapan Metode TOPSIS Untuk Sistem Pendukung Keputusan Penentuan Keluarga Miskin Pada Desa Panca Karsa II" telah membahas permasalahan pada pengembangan penelitian sebelumnya dengan metode AHP yang mengharapkan modifikasi dan penambahan kriteria dan subkriteria menjadi lebih lengkap. Permasalahan yang muncul pada proses pengembangan adalah semakin sulit untuk menentukan dan mengambil keputusan dalam perhitungan menggunakan metode AHP ketika terdapat banyak kriteria penentuan keluarga miskin. Untuk mengatasi permasalahan tersebut, dibuat sebuah sistem pendukung keputusan dengan menggunakan metode TOPSIS dengan teknologi PHP dan database MySQL. Hasil dari penelitian ini berupa aplikasi web yang menunjukan hasil analisa penentuan keluarga miskin (Muzakkir, 2017).

Pada penelitian sebelumnya yang berjudul "Sistem Pendukung Keputusan Penerimaan Pegawai di STMIK Royal Metode Simple Additive Weighting" telah membahas permasalahan penerimaan calon karyawan baru yang mengalami kesulitan dalam menyeleksi dan mengevaluasi pegawai yang berkompeten. Untuk mengatasi permasalahan tersebut, dibuat sebuah sistem pendukung keputusan menggunakan metode Simple Additive Weighting (SAW). Hasil dari penelitian ini adalah perhitungan perangkingan calon pegawai baru yang akan diterima (Afrisawati, 2018).

Pada penelitian sebelumnya yang berjudul "Sistem Penduknng Keputusan 
Penerimaan Karyawan Menggunakan Metode Analytical Hierarchy Process (AHP) Studi Kasus : RB. Nilam Sari Tembilahan" telah membahas permasalahan penerimaan calon karyawan baru RB. Nilam Sari Tembilahan yang masih dilakukan secara manual. Untuk mengatasi permasalahan tersebut, dibuat sebuah sistem pendukung keputusan dengan menggunakan metode Analytical Hierarchy Process (AHP). Hasil dari penelitian ini adalah aplikasi desktop yang dapat menampilkan hasil perhitungan perangkingan calon karyawan baru yang akan diterima (Rianto, 2016).

Pada penelitian ini dibangun sistem pendukung keputusan perekrutan karyawan di PT Visionet Data Internasional menggunakan metode TOPSIS. Sistem akan dibangun dalam bentuk website menggunakan framework Codeigniter dan database MySQL Sistem yang dibuat dapat digunakan dalam mengolah data penilaian karyawan baru berdasarkan kriteria penilaian perekrutan perusahaan. Hasil perangkingan sistem dapat dijadikan alternatif perusahaan dalam mengambil keputusan perekrutan karyawan baru.

Sistem pendukung keputusan adalah bagian dari sistem informasi berbasis komputer yang dipakai untuk mendukung pengambilan keputusan dalam suatu organisasi atau perusahaan. Sistem pendukung keputusan juga dapat dikatakan sebagai sistem komputer yang mengolah data menjadi informasi untuk mengambil keputusan dari masalah semi terstruktur yang spesifik (Syafrizal, 2010).

Multi Criteria Decision Making (MCDM) adalah salah satu teknik atau metode yang digunakan untuk memilih alternatif yang paling optimal dari beberapa kriteria untuk tujuan tertentu. Metode ini memberikan objektivitas dan membandingkan alternatif secara relatif untuk memperkirakan nilai prioritas alternatif yang digunakan sebagai opsi yang dapat mencapai tujuan keputusan.

Multi Criteria Decision Making (MCDM) banyak digunakan untuk menyelesaikan berbagai pengambilan keputusan, optimasi dan masalah prediksi. Pada penyelesaian masalah pengambilan keputusan, digunakan teknik MCDM seperti Analytical Hierarchy Process (AHP), Fuzzy Logic Decision Making (FLCM), Weighted Sum Method (WSM), Weighted Product
Method (WPM), EVAMIX dan ELECTRE (Majumder \& Saha, 2016).

Metode TOPSIS merupakan salah satu metode MCDM dengan konsep memilih alternatif dengan jarak terdekat dengan solusi ideal positif dan memiliki jarak terjauh dari jarak ideal negatif (Balioti, Tzimopoulos, \& Evangelides, 2018). Metode TOPSIS digunakan karena memiliki kelebihan seperti konsepnya yang sederhana dan mudah dipahami, komputasinya efisien dan memiliki kemampuan untuk mengukur kinerja relatif dari alternatif - alternatif keputusan dalam bentuk matematis yang sederhana (Somya \& Wardoyo, 2019). Metode ini secara umum memiliki langkah penyelesaian seperti berikut ini (Murnawan \& Siddiq, 2012): 1) Membuat matriks keputusan yang sudah dinormalisasi; 2) Membuat matriks keputusan normalisasi terbobot; 3) Menentukan matriks solusi ideal positif dan matriks solusi ideal negatif; 4) Menentukan jarak antara setiap nilai alternatif dengan matriks solusi ideal positif dan matriks solusi ideal negatif; 5) Menghitung nilai preferensi untuk setiap nilai alternatif.

\section{Metode Penelitian}

Metode penelitian yang dilakukan terbagi dalam delapan tahapan, yaitu: 1) Identifikasi masalah, 2) Studi literatur, 3) Pengumpulan data, 4) Pemodelan, 5) Analisis dan desain sistem, 6) Pembuatan sistem, 7) Pengujian sistem, 8) Kesimpulan. Delapan tahapan penelitian ditunjukan pada Gambar 1.

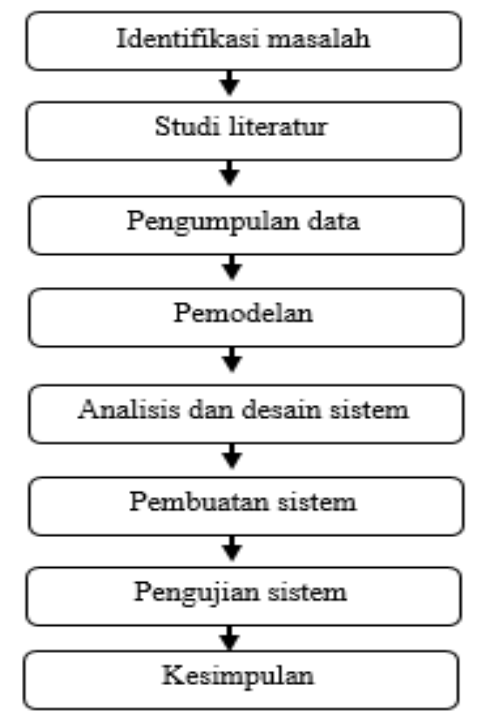

Gambar 1. Tahapan Penelitian

Tahapan penelitian pada Gambar 1 dapat dijelaskan sebagai berikut: Tahap pertama adalah identifikasi masalah yang 
terkait dengan proses analisis permasalahan yang ada. Permasalahan yang dianalisis yaitu bagaimana proses perancangan sistem pendukung keputusan perekrutan karyawan di PT Visionet Data Internasional.

Tahap kedua adalah studi literatur yang terkait proses mempelajari dan memahami teori - teori yang digunakan. Beberapa teori yang dipelajari diantaranya faktor yang mendukung penggunakan sistem pendukung keputusan, metode TOPSIS dan teori perekrutan karyawan.

Tahap ketiga adalah pengumpulan data yang dilakukan dengan wawancara melalui email kepada pihak terkait PT Visionet Data Internasional. Data yang didapatkan berupa kriteria penilaian terhadap calon karyawan baru.

Tahap keempat adalah pemodelan yang terkait dengan proses pengolahan data sampel menggunakan metode TOPSIS. Hasil pengolahan yang dilakukan berupa data hasil perangkingan secara manual.

Tahap kelima adalah analisis dan desain sistem yang terkait proses pengumpulan informasi sistem yang akan dibuat, perancangan model dan alur pembangunan sistem.

Tahap keenam adalah pembuatan sistem yang terkait dengan implementasi hasil analisis dan desain sistem. Pada tahapan ini, metode TOPSIS diterapkan kedalam sistem untuk dapat mengolah data penilaian calon karyawan baru.

Tahap ketujuh adalah pengujian sistem yang terkait pengujian hasil pembuatan sistem. Pengujian yang dilakukan pada berupa pencocokan hasil perangkingan manual dengan hasil perangkingan sistem dan fungsi - fungsi yang berjalan dalam sistem. Tahap kedelapan adalah kesimpulan yang terkait dengan proses penyimpulan hasil penelitian yang telah dilakukan.

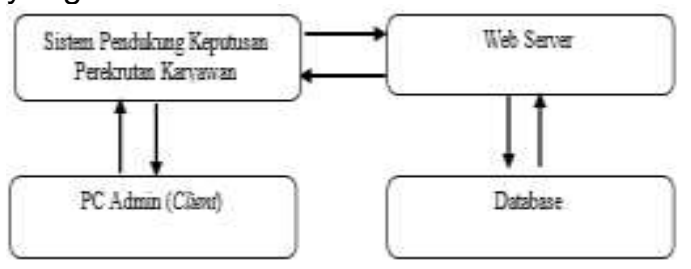

Gambar 2. Arsitektur Sistem

Pada Gambar 2 menunjukan perancangan dari sistem pendukung keputusan perekrutan karyawan. Sistem pendukung keputusan perekrutan karyawan akan terhubung dengan web server agar dapat melayani request dari HTTP Client. Data dari Client akan akan disimpan dan dapat diambil melalui database. Perancangan sistem dibuat melalui diagram UML (Unified Modeling Language) dengan beberapa diagram seperti usecase diagram, activity diagram, sequence diagram dan class diagram. Rancangan yang dibuat menggambarkan segala proses aplikasi yang diketahui dan digunakan sebagai dasar dari pembuatan sistem.

Perancangan sistem ini dibangun menggunakan Unified Modeling Language (UML) dengan beberapa diagram seperti usecase diagram, activity diagram, sequence diagram dan class diagram. Usecase diagram digunakan untuk menggambarkan fungsionalitas sistem secara abstrak. Usecase diagram terkait dengan apa yang dapat user lakukan dalam sistem dan siapa saja yang terlibat (Nugroho, 2019).

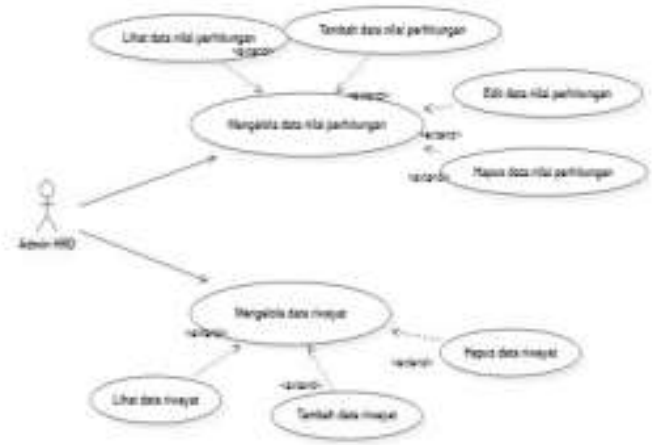

Gambar 3. Use Case Diagram Sistem

Pada Gambar 3 menjelaskan usecase diagram dari sistem. Aktor utama dari sistem adalah Admin HRD yang dapat mengelola data nilai perhitungan dan mengelola data riwayat setelah berhasil melakukan login. Dalam mengelola data nilai perhitungan, Admin HRD dapat melihat data nilai perhitungan, menambah data nilai perhitungan, mengedit data nilai perhitungan dan menghapus data nilai perhitungan. Dalam mengelola data riwayat, Admin HRD dapat melihat data riwayat, menambah data riwayat dan menghapus data riwayat.

Activity diagram digunakan untuk memodelkan proses dan alur kerja use case diagram. Pada umumnya, pada sebuah sistem terdapat banyak activity diagram (Nugroho, 2019). 


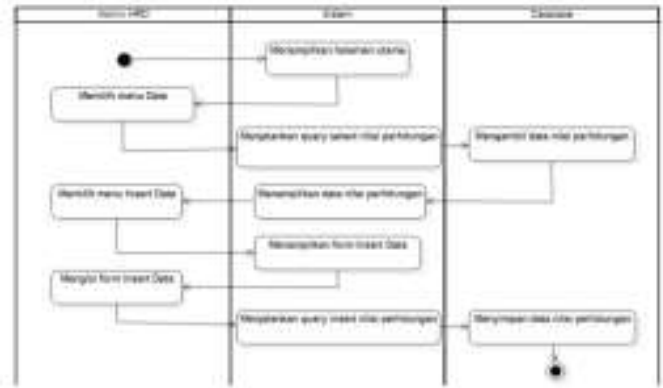

Gambar 4. Activity Diagram Menambah

Data Nilai Perhitungan Sistem

Pada Gambar 4 menjelaskan activity diagram untuk proses menambahkan data nilai perhitungan. Proses ini dimulai dengan sistem yang menampilkan halaman data perhitungan seperti pada activity diagram menampilkan data perhitungan. Kemudian Admin HRD perlu memilih menu Insert Data. Setelah itu sistem akan menampilkan form tambah data untuk diisi oleh Admin HRD.. Setelah form tambah data terisi, sistem akan mengirim query insert data nilai perhitungan ke database. Database akan menyimpan data nilai perhitungan yang telah diisi.

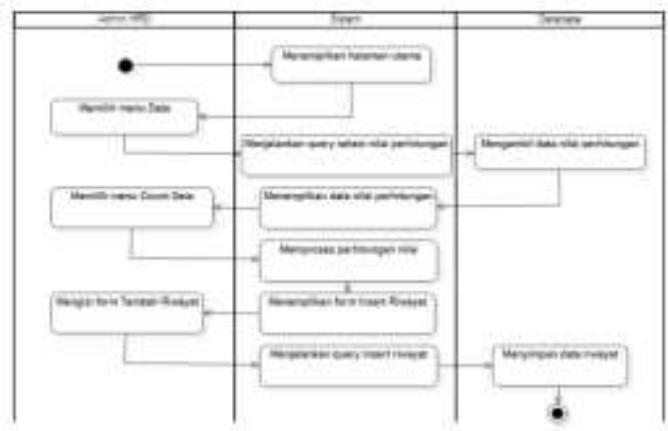

Gambar 5. Activity Diagram Menambah Data Riwayat Sistem

Pada Gambar 5 menjelaskan activity diagram untuk proses menambahkan data riwayat. Proses ini dimulai dengan sistem yang menampilkan halaman Data seperti pada activity diagram menampilkan data perhitungan. Kemudian Admin HRD perlu memilih menu Count Data. Setelah itu sistem akan memproses perhitungan nilai dan menampilkan form tambah riwayat untuk diisi. Setelah form tambah riwayat telah terisi, sistem akan mengirim query insert riwayat ke database. Database akan menyimpan data riwayat yang telah diisi.

Sequence diagram digunakan untuk memodelkan urutan interaksi antara objek dengan fokus pada waktu. Sequence diagram digambarkan dengan garis vertikal dengan alur kerja dari atas ke bawah (Nugroho, 2019).

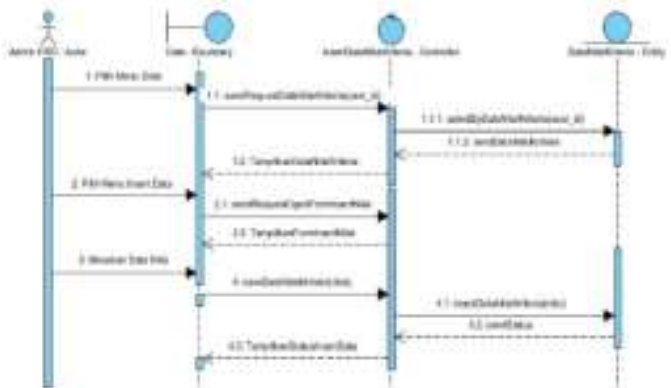

Gambar 6. Sequence Diagram Menambah Data Nilai Perhitungan Sistem

Pada Gambar 6 menjelaskan sequence diagram untuk urutan proses menambah data nilai perhitungan. Untuk proses awalnya, Admin HRD harus melakukan proses melihat Data seperti pada sequence diagram melihat data nilai perhitungan. Kemudian, Admin HRD perlu memilih menu Insert Data. Boundary mengirim permintaan membuka form tambah data ke controller. Controller akan merespon permintaan boundary dengan membuka form tambah data. Setelah form tambah data muncul, Admin HRD perlu memasukan data nilai perhitungan. Kemudian, boundary akan mengirim data nilai perhitungan yang sudah dimasukan ke bagian controller. Dari bagian controller akan mengirimkan query insert data nilai perhitungan ke bagian entity data nilai kriteria. Setelah itu, entity akan menyimpan data nilai kriteria dan mengirim respon status permintaan insert data ke controller. Dari controller akan mengirimkan status insert data ke boundary.



Gambar 7. Sequence Diagram Menambah Data Riwayat Sistem

Pada Gambar 7 menjelaskan sequence diagram untuk urutan proses menambahkan data riwayat. Untuk proses awalnya, Admin HRD harus melakukan proses melihat Data seperti pada sequence diagram melihat data nilai perhitungan. Kemudian, Admin HRD perlu memilih menu Count Data. Boundary mengirim permintaan membuka form tambah riwayat perhitungan ke controller. Controller akan merespon permintaan boundary 
memproses rangking dan menampilkan data rangking dalam form tambah data riwayat perhitungan. Setelah form tambah data riwayat perhitungan muncul, Admin HRD perlu memasukan data riwayat perhitungan. Kemudian, boundary akan mengirim data riwayat perhitungan yang sudah dimasukan ke bagian controller. Dari bagian controller akan mengirimkan query insert data riwayat perhitungan ke bagian entity data riwayat perhitungan. Setelah itu, entity akan menyimpan data riwayat perhitungan dan mengirim respon status permintaan insert data ke controller. Dari controller akan mengirimkan status insert data ke boundary.

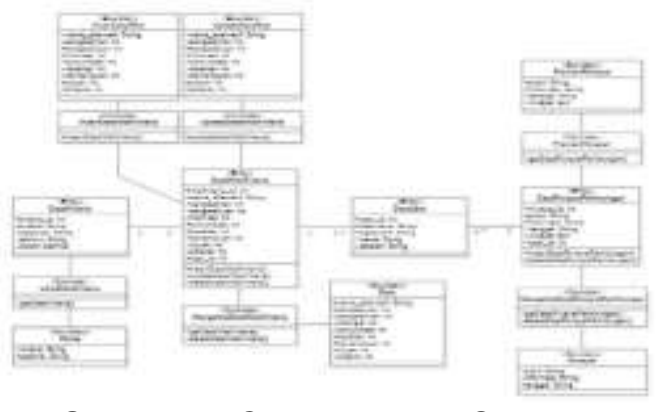

Gambar 8. Class Diagram Sistem

Class diagram digunakan untuk menggambarkan hubungan antara satu dengan yang lain diantara kelas - kelas yang ada dalam sebuah sistem (Nugroho, 2019). Pada Gambar 8 menjelaskan class diagram sistem yang dibangun. Class diagram yang telah dibuat pada umumnya menggunakan konsep model, view dan control. Model atau entity berfungsi menangani semua fungsi yang berhubungan dengan database. View atau boundary berfungsi menampilkan interface yang berhubungan langsung dengan user. Control atau controller berfungsi menghubungkan perintah antara model dan view.

\section{Hasil dan Pembahasan}

Hasil dan pembahasan meliputi tentang proses pembuatan sistem pendukung keputusan perekrutan karyawan, pembahasan perhitungan dengan metode TOPSIS dan pengujian sistem. Pada sistem yang dibuat terdapat beberapa halaman utama untuk proses perangkingan penilaian, diantaranya adalah mengolah data penilaian dan memproses serta menampilkan hasil perhitungan perangkingan.

Pada menu mengolah data penilaian, Admin HRD dapat melihat, menambahkan, mengedit dan menghapus data penilaian.
Admin HRD dapat mengakses menu mengolah data penilaian setelah melakukan proses login dan memilih menu Data.

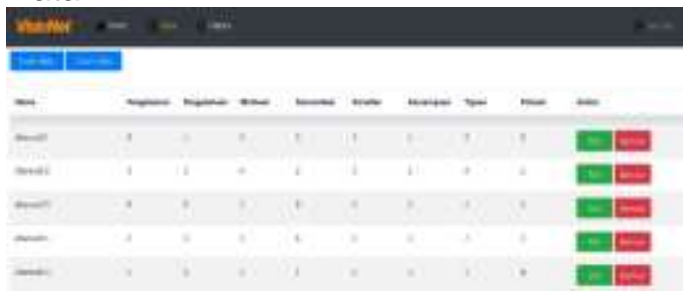

Gambar 9. Tampilan Menu Data

Pada Gambar 9 menampilkan tampilan untuk halaman data. Pada halaman ini Admin HRD dapat melakukan proses tambah data, hitung data, edit data dan hapus data.
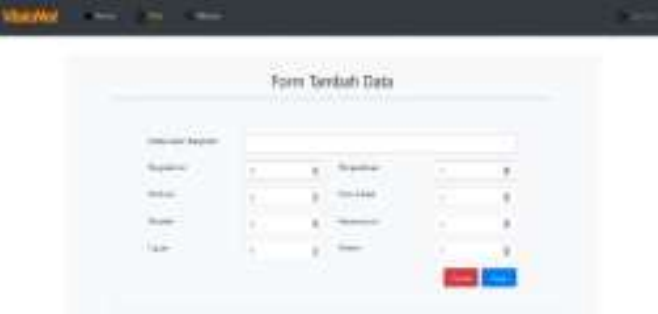

\section{Gambar 10. Tampilan Form Tambah Penilaian}

Pada Gambar 10 menampilkan tampilan untuk form tambah data. Pada form tambah data, Admin HRD dapat membatalkan proses menambah data dan melakukan proses menambah data dengan memasukan nama calon karyawan dan penilaian kriteria - kriteria perekrutan calon karyawan baru.

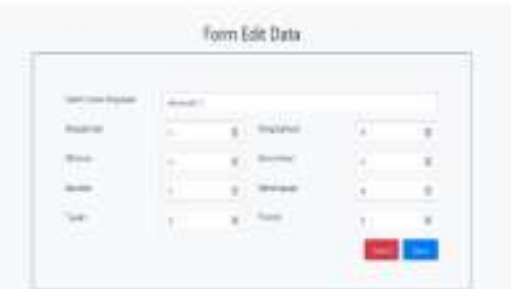

Gambar 11. Tampilan Form Edit Penilaian Pada Gambar 11 menampilkan tampilan untuk form edit data. Form edit data akan menampilkan nama calon karyawan dan data penilaian calon karyawan baru yang dipilih pada menu Data. Admin HRD dapat membatalkan proses mengedit data dan melakukan proses mengedit data penilaian perekrutan calon karyawan baru. 


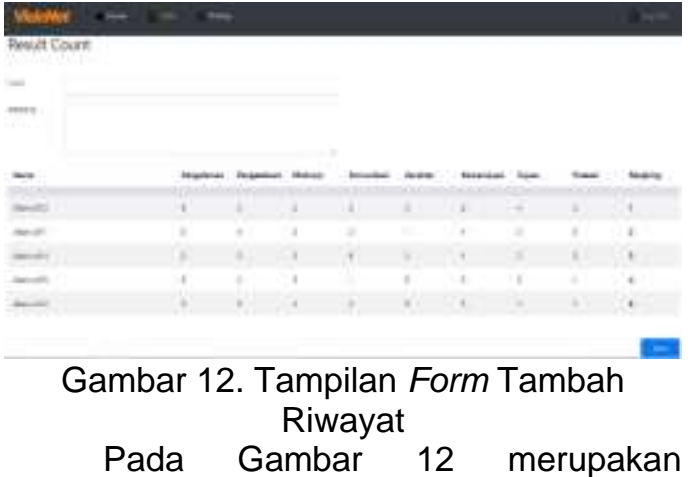
tampilan hasil perhitungan perangkingan dari sistem yang menjadi satu dengan form tambah data riwayat. Pada halaman ini Admin HRD dapat melihat hasil perhitungan perangkingan calon karyawan baru berdasarkan data penilaian pada menu Data. Data hasil perangkingan sistem akan dirangking berdasarkan rangking terbaik dari hasil perangkingan calon karyawan baru.

Tabel 1. Data Simulasi Penilaian

\begin{tabular}{lllllllll}
\hline & C1 & C2 & C3 & C4 & C5 & C6 & C7 & C8 \\
\hline A1 & 5 & 4 & 3 & 3 & 1 & 4 & 3 & 5 \\
\hline A2 & 3 & 3 & 4 & 2 & 5 & 3 & 4 & 2 \\
\hline A3 & 6 & 5 & 2 & 5 & 3 & 2 & 4 & 3 \\
\hline A4 & 2 & 3 & 3 & 6 & 3 & 4 & 2 & 3 \\
\hline A5 & 5 & 2 & 5 & 1 & 5 & 3 & 3 & 4 \\
\multicolumn{5}{c}{ Pada } & \multicolumn{5}{c}{ pembahasan } & \multicolumn{3}{c}{ proses }
\end{tabular}
perhitungan TOPSIS, digunakan data simulasi penilaian seperti pada Tabel 1. Pada Tabel 1, terdapat 5 alternatif karyawan baru yaitu A1, A2, A3, A4 dan A5. Selain itu terdapat 8 kriteria penilaian karyawan baru, yaitu pengalaman (C1), pengetahuan (C2), motivasi (C3), komunikasi (C4), karakter (C5), kemampuan (C6), tujuan (C7) dan potensi (C8). Pada proses perhitungan TOPSIS ini, ditetapkan penilaian kriteria dengan rentang nilai 1 sampai 6 dengan semua kriteria beratribut maksimum (benefit). Untuk bobot $(\mathrm{w})$ yang ditetapkan masing masing adalah $0.1515,0.1515,0.0909$, $0.1212,0.1212,0.1515,0.0606$ dan 0.1515 .

Pada langkah pertama, data simulasi akan diubah menjadi matriks sebagai berikut:

$A_{i j}=\begin{array}{llllllll}5 & 4 & 3 & 3 & 1 & 4 & 3 & 5 \\ 3 & 3 & 4 & 2 & 5 & 3 & 4 & 2 \\ 6 & 5 & 2 & 5 & 3 & 2 & 4 & 3 \\ 2 & 3 & 3 & 6 & 3 & 4 & 2 & 3 \\ 5 & 2 & 5 & 1 & 5 & 3 & 3 & 4\end{array}$

Pada langkah berikutnya, menentukan matriks normalisasi $R$ dengan Rumus 1. $r_{i j}=\frac{a_{i j}}{\sqrt{\sum_{i=1}^{m} a_{i j}^{2}}}$

Proses normalisasi matriks dilakukan dengan membagi data nilai kriteria setiap calon karyawan baru dengan akar kuadrat penjumlahan total nilai kriteria. Hasil matriks normalisasi $\mathrm{R}$ ditunjukan pada Gambar 13.

$\begin{array}{lllllllll}0.5025 & 0.5039 & 0.3779 & 0.3464 & 0.1203 & 0.5443 & 0.4082 & 0.6299\end{array}$ $\begin{array}{lllllllll}0.3015 & 0.3779 & 0.5039 & 0.2309 & 0.6019 & 0.4082 & 0.5443 & 0.2519\end{array}$ $R_{i j}=\begin{array}{llllllllll}0.6030 & 0.6299 & 0.2519 & 0.5773 & 0.3611 & 0.2721 & 0.5443 & 0.3779\end{array}$ $\begin{array}{lllllllll}0.2010 & 0.3779 & 0.3779 & 0.6928 & 0.3611 & 0.5443 & 0.2721 & 0.3779\end{array}$ $\begin{array}{llllllll}0.5025 & 0.2519 & 0.6299 & 0.1154 & 0.6019 & 0.4082 & 0.4082 & 0.5039\end{array}$ Gambar 13. Matriks Normalisasi R

Pada langkah kedua, menentukan matriks normalisasi terbobot dengan Rumus 2.

$y_{i j}=w_{i} r_{i j}$

Matriks normalisasi terbobot $Y$ didapatkan dengan mengkali data penilaian setiap kriteria dengan bobot kriteria, Hasil matriks normalisasi terbobot $Y$ ditunjukan pada Gambar 14.

$\begin{array}{llllllll}2.5125 & 2.5195 & 1.1337 & 1.3856 & 0.4812 & 2.7215 & 0.8164 & 3.1495\end{array}$ $\begin{array}{lllllllll}1.5075 & 1.8895 & 1.5117 & 0.9236 & 2.4076 & 2.0410 & 1.0886 & 1.2595\end{array}$



$\begin{array}{llllllll}1.0050 & 1.8895 & 1.1337 & 2.7712 & 1.444 & 2.7215 & 0.5442 & 1.8895\end{array}$ $\begin{array}{llllllll}2.5125 & 1.2595 & 1.8897 & 0.4616 & 2.4076 & 2.0410 & 0.8164 & 2.5195\end{array}$ Gambar 14. Matriks Normalisasi Terbobot $Y$

Pada langkah ketiga, menentukan matriks solusi ideal positif $A^{+}$dan solusi ideal negatif $A^{-}$dengan Rumus 3 dan Rumus 4.

$A^{+}=\left\{\left(\max _{i} y_{i j}\right),\left(\min _{i} y_{i j}\right)\right\}=\left\{y_{j}^{+}\right\}$

$A^{-}=\left\{\left(\min _{i} y_{i j}\right),\left(\max _{i} y_{i j}\right)\right\}=\left\{y_{j}^{-}\right\}$

Matriks solusi ideal positif $A^{+}$diperoleh dengan mengambil nilai maksimal untuk atribut kriteria benefit dan nilai minimal untuk atribut kriteria cost pada setiap kolom kriteria. Sedangkan matriks solusi ideal negatif $A^{-}$diperoleh dengan mengambil nilai minimal untuk atribut kriteria benefit dan nilai maksimal untuk atribut kriteria cost. Hasil matriks solusi ideal positif $A^{+}$dan solusi ideal negatif $A^{-}$ditunjukan pada Gambar 15.

$A^{4}=3.0150 \quad 3.1495 \quad 18897 \quad 27712 \quad 24076 \quad 2.7215 \quad 1.0886 \quad 3.1495$ $A^{\prime}=1.0050 \quad 1.2595 \quad 0.7557 \quad 0.4616 \quad 0.4812 \quad 1.3605 \quad 0.5442 \quad 1.2595$

Gambar 15. Hasil Perhitungan $A^{+}$dan $A^{-}$

Pada langkah keempat, ditentukan jarak setiap nilai alternatif dengan matriks solusi ideal positif $D^{+}$dan solusi ideal negatif $D^{-}$dengan Rumus 5 dan Rumus 6 .

$D_{i}^{+}=\sqrt{\sum_{j=1}^{m}\left(A_{i j}-A_{j}^{+}\right)^{2}}$ 


$$
D_{i}^{-}=\sqrt{\sum_{j=1}^{m}\left(A_{i j}-A_{j}^{-}\right)^{2}}
$$

Jarak setiap nilai alternatif dengan matriks solusi ideal positif $D^{+}$diperoleh dengan menghitung akar dari kuadrat penjumlahan nilai alternatif pada setiap kriteria yang sudah dikurangi dengan nilai kolom matriks solusi ideal positif. Sedangkan jarak setiap nilai alternatif dengan matriks solusi ideal negatif $D^{-}$ diperoleh dengan menghitung akar dari kuadrat penjumlahan nilai alternatif pada setiap kriteria yang sudah dikurangi dengan nilai kolom matriks solusi ideal negatif.

Tabel 2. Hasil Perhitungan $D^{+}$

\begin{tabular}{lll}
\hline Nama & $\boldsymbol{D}^{+}$ & Rangking \\
\hline A1 & 2.6316 & 2 \\
\hline A2 & 3.3840 & 5 \\
A3 & 2.4223 & 1 \\
\hline A4 & 3.0019 & 3 \\
\hline A5 & 3.1769 & 4 \\
\hline
\end{tabular}

Tabel 3. Hasil Perhitungan $D^{-}$

\begin{tabular}{lll}
\hline Nama & $\boldsymbol{D}^{-}$ & Rangking \\
\hline A1 & 3.2179 & 2 \\
\hline A2 & 2.4299 & 5 \\
\hline A3 & 3.5561 & 1 \\
\hline A4 & 3.0084 & 4 \\
\hline A5 & 3.0649 & 3 \\
\hline
\end{tabular}

Hasil perhitungan jarak setiap nilai alternatif dengan matriks solusi ideal positif $D^{+}$dan solusi ideal negatif $D^{-}$ditunjukan pada Tabel 2 dan Tabel 3. Karena hasil perhitungan dari Tabel 2 dan Tabel 3 tidak sama, maka akan dilanjutkan proses perhitungan nilai preferensi positif $C^{+}$dan negatif $C^{-}$. Nilai preferensi positif $C^{+}$dan negatif $C^{-}$akan menunjukan hasil yang sama dengan menggunakan Rumus 7 dan Rumus 8.

$C_{i}^{+}=D_{i}^{+} /\left(D_{i}^{+}+D_{i}^{-}\right)$

$C_{i}^{-}=D_{i}^{-} /\left(D_{i}^{+}+D_{i}^{-}\right)$

Nilai preferensi positif $C^{+}$didapatkan dengan membagi setiap baris $D^{+}$dengan penjumlahan baris $D^{+}$dan $D^{-}$. Sedangkan nilai preferensi negatif $C^{-}$didapatkan dengan membagi setiap baris $D^{-}$dengan penjumlahan baris $D^{+}$dan $D^{-}$.

Tabel 4. Hasil Perhitungan $C^{+}$

\begin{tabular}{lll}
\hline Nama & $\boldsymbol{C}^{+}$ & Rangking \\
\hline A1 & 0.4498 & 2 \\
\hline A2 & 0.5820 & 5 \\
\hline A3 & 0.4051 & 1 \\
\hline A4 & 0.4994 & 3 \\
\hline A5 & 0.5089 & 4 \\
\hline
\end{tabular}

Tabel 5. Hasil Perhitungan $C^{-}$

\begin{tabular}{lllll}
\hline Nama & $\boldsymbol{C}^{-}$ & \multicolumn{2}{c}{ Rangking } \\
\hline A1 & 0.5501 & 2 & \\
A2 & 0.4179 & 5 & \\
A3 & 0.5948 & 1 & \\
A4 & 0.5005 & 3 & \\
\hline A5 & 0.4910 & 4 & \\
\hline & Berdasarkan & Tabel 4 & maupun
\end{tabular}

Tabel 5, diperoleh hasil perangkingan karyawan baru dari urutan terbaik $\mathrm{A} 3, \mathrm{~A} 1$, A3, A5 dan A2. Hasil perangkingan tersebut adalah contoh alternatif keputusan yang dapat diambil perusahaan dalam proses perekrutan karyawan baru. Hasil penerapan perangkingan pada sistem ditunjukan pada Gambar 16.

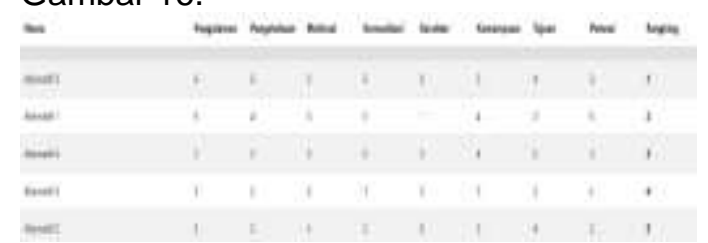

Gambar 16. Hasil Perangkingan Sistem Pengujian aplikasi dilakukan untuk mengecek fungsi yang berjalan dalam sistem dengan menggunakan pengujian metode blackbox. Blackbox merupakan pengujian fungsionalitas tanpa memperhatikan alur eksekusi program. Pengujian fungsionalitas yang dimaksud adalah pengujian yang berfokus pada apakah fungsi dalam aplikasi telah berjalan dengan semestinya. Pengujian aplikasi menggunakan metode blackbox dapat dilihat pada Tabel 6 .

Tabel 6. Pengujian Blackbox

\begin{tabular}{|c|c|c|}
\hline No. & Modul yang Diuji & $\begin{array}{l}\text { Hasil } \\
\text { Pengujian }\end{array}$ \\
\hline 1 & Login user & Valid \\
\hline 2 & Menu Home & Valid \\
\hline 3 & Menu Data & Valid \\
\hline 4 & Insert penilaian & Valid \\
\hline 5 & Edit penilaian & Valid \\
\hline 6 & Remove penilaian & Valid \\
\hline 7 & $\begin{array}{l}\text { Action batal Insert / Edit } \\
\text { penilaian }\end{array}$ & Valid \\
\hline 8 & Count rangking & Valid \\
\hline 9 & $\begin{array}{l}\text { Action menyimpan data } \\
\text { perangkingan }\end{array}$ & Valid \\
\hline 10 & $\begin{array}{l}\text { Action batal menyimpan } \\
\text { data perangkingan }\end{array}$ & Valid \\
\hline 11 & Menu Riwayat & Valid \\
\hline 12 & View riwayat & Valid \\
\hline 13 & Delete riwayat & Valid \\
\hline
\end{tabular}


kebutuhan pengguna. Sistem yang dibuat tergolong mudah untuk digunakan dan dapat membantu pihak PT Visionet Data Internasional untuk mendapatkan alternatif keputusan karyawan baru berdasarkan kriteria perekrutan perusahaan.

\section{Kesimpulan}

Berdasarkan hasil penelitian dan pengujian yang dilakukan, maka dapat disimpulkan bahwa sistem pendukung keputusan perekrutan karyawan pada PT Visionet Data Internasional dapat membantu perusahaan dalam menyediakan alternatif pengambilan keputusan saat perekrutan karyawan baru. Sistem bekerja dengan mengolah data calon karyawan baru berdasarkan kriteria dengan menentukan alternatif terbaik menggunakan metode TOPSIS. Sistem yang dibangun juga dilengkapi dengan menu riwayat yang akan memudahkan Admin HRD dalam melihat kembali data perhitungan perekrutan karyawan yang sudah pernah dilakukan. Adapun saran yang diperlukan untuk sistem ini adalah mengenai tampilan sistem, penambahan autentikasi keamanan dan penambahan atau pembaharuan fungsi yang ada untuk mengoptimalkan kerja dari sistem.

\section{Referensi}

Afrisawati. (2018). Sistem Pendukung Keputusan Penerimaan Pegawai di STMIK Royal Metode Simple Additive Weighting, $V(1), 1-8$.

Balioti, V., Tzimopoulos, C., \& Evangelides, C. (2018). Multi-Criteria Decision Making Using TOPSIS Method Under Fuzzy Environment . Application in, 18.

https://doi.org/10.3390/proceedings21 10637

Majumder, M., \& Saha, A. K. (2016). Impact of Climate Change on Hydro-Energy Potential. https://doi.org/10.1007/978981-287-305-7

Murnawan, \& Siddiq, A. F. (2012). Sistem Pendukung Keputusan Menggunakan Metode Technique for Order by Similarity to Ideal Solution (TOPSIS), 4(1), 398-412.

Muzakkir, I. (2017). Penerapan Metode TOPSIS untuk Sistem Pendukung Keputusan Penentuan Keluarga Miskin Pada Desa Panca Karsa ii, 9, 274-281.

Nugroho, S. (2019). Object Oriented Analysis.

Rianto, B. (2016). Sistem Pendukung
Keputusan Penerimaan Karyawan Menggunakan Metode Analytical Hierarchy Process ( AHP ) Studi Kasus: RB . Nilam Sari Tembilahan, 2(2), 29-38.

Somya, R., \& Wardoyo, R. (2019). Perancangan Sistem Pendukung Keputusan Seleksi Asisten Dosen Menggunakan Kombinasi Metode Profile Matching dan TOPSIS Berbasis Web Service, 5(1), 44-50.

Syafrizal, M. (2010). Sistem Pendukung Keputusan (Decision Support System), 11(3), 77-90.

Widianto, A. T. (2016). Sistem Pendukung Keputusan Dalam Menentukan Karyawan Terbaik Pada PT Tembaga Mulia Semanan Dengan Metode TOPSIS. 